\title{
Seasonal changes in phytoplankton and bacterioplankton distribution at the ice-water interface in the Antarctic neritic area
}

\author{
D. Delille ${ }^{1}$, M. Fiala ${ }^{1}$, C. Rosiers ${ }^{2}$ \\ ${ }^{1}$ Observatoire Océanologique de Banyuls, Laboratoire Arago, Université P. et M. Curie, URA CNRS 117, \\ F-66650 Banyuls-sur-Mer, France \\ ${ }^{2}$ Université Claude Bernard (Lyon 1), Bât. 405, 43 Bd du 11 Novembre 1918, F-69622 Villeurbanne Cedex, France
}

\begin{abstract}
To determine the relationship between phytoplankton and bacteria biomass near the icewater interface in the Antartic, the seasonal distributions of phytoplankton and bacteria populations were investigated on the continental shelf of Terre Adélie during the ice coverage period. An under-ice surface station was sampled weekly from March 1991 to January 1992 for the bottom ice and for surface, 0.5 and $2 \mathrm{~m}$ depth seawater. Seawater chlorophyll a values ranged from $0.9 \mathrm{mg} \mathrm{m}^{-3}$ in summer to $0.01 \mathrm{mg} \mathrm{m}^{-3}$ in winter. Values 50 times higher were recorded in the overlying ice. Bacterial abundance ranged from $0.5 \times 10^{11}$ cells $\mathrm{m}^{-3}$ in July to $6.0 \times 10^{11}$ cells $\mathrm{m}^{-3}$ after the ice break-up. Values reaching up to $2.5 \times 10^{12}$ cells $\mathrm{m}^{-3}$ were recorded in sea ice. Bacterial biomass and chlorophyll a concentrations were significantly correlated in both sea ice and underlying seawater. Bacterial biomass represents between 1 and $10 \%$ of total microbial biomass in sea ice and from $10 \%$ (summer) to up to $90 \%$ (winter) of the living community in the underlying seawater.
\end{abstract}

KEY WORDS: Phytoplankton B Bacterioplankton $\cdot$ POC $\cdot$ Seasonal variations - Sea ice Antarctica

\section{INTRODUCTION}

Seasonal changes in critical parameters should not be disregarded if accurate carbon budgets are to be constructed (Platt et al. 1992). An intense temporal variability occurs in Antarctic seawaters, representing perhaps the most extreme seasonality observed anywhere in the world ocean (Karl 1993). Few investigators have examined the distribution of both bacteria and phytoplankton over an annual cycle. During interannual investigations, Ducklow \& Shiah (1993) report low covariation of phytoplankton with bacteria in Chesapeake Bay, USA. Accordingly, the 3 yr survey of Hoch \& Kirchman (1993) did not show a significant correlation between chlorophyll a (chl a) concentration and bacterial abundance in a temperate estuary. As a general trend, a number of other investigators working in subtropical (Hopkinson et al. 1989), temperate (Velimirov \& Walenta-Simon 1992, Ducklow et al. 1993) and subpolar (Delille 1990, Wiebe et al. 1993) coastal marine systems have reported no direct relationship between seasonal changes in bacterial biomass and phytoplankton.

The pathways that mediate the transfer of nutrients between the primary producers and bacteria in seawater are extremely complex and include numerous feedback mechanisms. Heterotrophic bacteria are largely reliant on phytoplankton for their energy supply, either directly through excretion of dissolved organic matter (Lancelot \& Billen 1984, Kuosa \& Kivi 1989, Suttle et al. 1991) or indirectly after decomposition of dead phytoplankton cells (Riemann \& Sondergaard 1986). On the other hand, it is generally assumed that most of the primary production in pelagic ecosystems is sustained by a continuous and rapid recycling of the growth-limiting inorganic nutrients (Azam et al. 1983, Berman et al. 1987). Depending on food web structure, bacteria may be either a link in food webs, supporting metazoan production, or largely a sink, where bacterial production is respired by microorganisms (Ducklow et al. 1986, 
Pomeroy \& Deibel 1986, Wylie \& Currie 1991, Vaqué et al. 1992). Estimates of ratios of phytoplankton primary production to community respiration suggest that many parts of the ocean margins are net heterotrophic in all but the coldest season (Smith \& Mackenzie 1987). Seasonal changes in growth rates and respiratory demands of aerobic heterotrophic bacteria, which dominate total community respiration, can induce change from general heterotrophy to autotrophy (Hopkinson 1985, Griffith et al. 1990, Wiebe et al. 1993). Furthermore, Wiebe et al. (1993) proposed that temperature-substrate interactions underlie seasonal cycles of bacterial activity. It is therefore of considerable interest to study seasonal cycles under an ice-covered system where temperature can be considered as relatively constant. The purpose of the present article is to examine the relationship between phytoplankton and bacteria biomass on the continental shelf of the Terre Adélie area, Antartica, during the ice covered period. The study comprises some of the first composite information on the seasonal dynamics of phytoplankton and bacterial communities occurring in such areas.

\section{MATERIALS AND METHODS}

Study site and sampling strategy. The study was conducted from March 1991 to January 1992 in Terre Adélie $\left(66^{\circ} 40^{\prime} \mathrm{S}, 140^{\circ} 01^{\prime} \mathrm{E}\right)$. Samples were collected weekly at the under-ice Stn B (10 m deep) located in the vicinity of the Pointe Géologie Archipelago (Fig. 1).

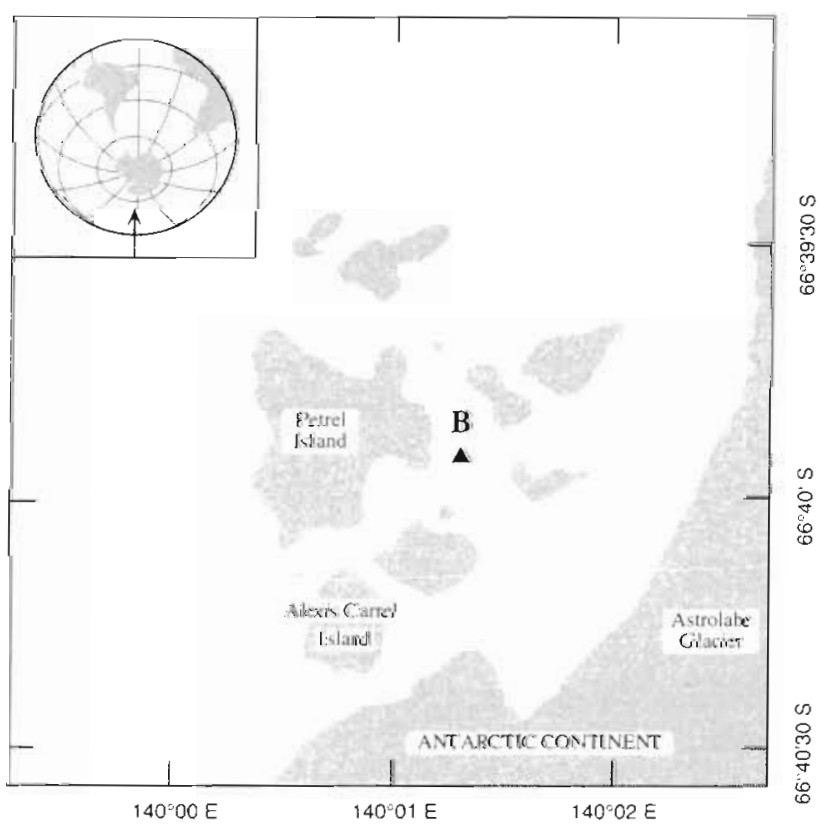

Fig. 1. The Pounte Géologie Archipelago (Terre Adélie), showing the location of the study station (B)
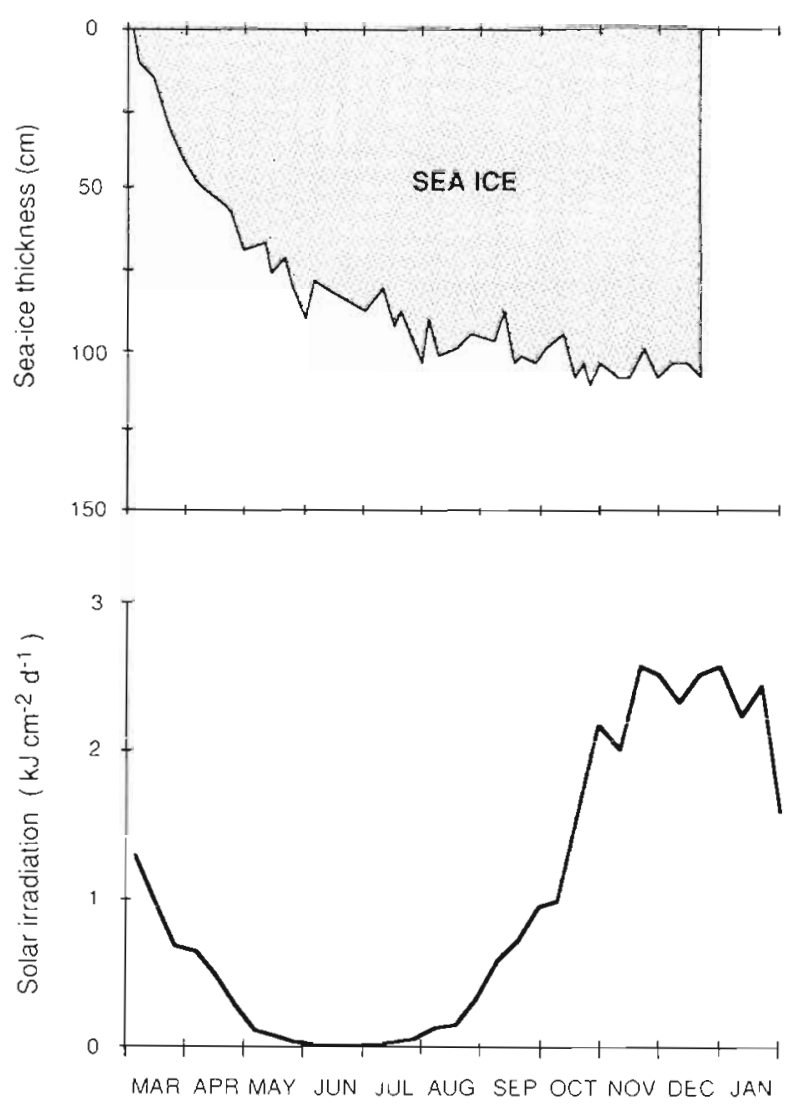

Fig. 2. Seasonal changes in ice coverage and global irradiation recorded at $\mathrm{Stn} B$

Ice cores were collected using $10 \mathrm{~cm}$ (internal diameter) ice-coring augers. The bottom part (last $10 \mathrm{~cm}$ ) of the cores was cut with a sterile blade and stored in a sterile glass box before melting in a known quantity of sterile aged seawater After drlling of the ice cover, subsurface seawater samples were collected with sterile glass bottles at $0,0.5$ and $2 \mathrm{~m}$ depth. All samples were analysed in the laboratory within $15 \mathrm{~min}$.

Chlorophyll biomass. Seawater was filtered through Whatman GF/F glass fiber filters under gentle vacuum (<5 mm Hg). Measurements of chlorophylls and phaeopigments were carried out using the spectrofluorometric method developed by Neveux \& Panouse (1987). Chlorophylls and derived pigments were extracted with $90 \%$ acetone and their concentrations measured using a spectrofluorometer (Perkin Elmer MPF 66) at 6 coupled wavelengths. Each coupled wavelength corresponded to the fluorescence excitation and emission of each analysed pigment: $c h l a, c h l b, c h l c$ and phaeophytins (phaeo) $a, b$ and $c$. A solid sample of phaeophytin $a$ in polymethylmethacrylate was used as a reference.

The $\mathrm{C}$ biomass of phytoplankton was estmmated from chlorophyll measurements using a $\mathrm{C} / \mathrm{chl}$ a factor of 60 according to Neori \& Holm-Hansen (1982). 

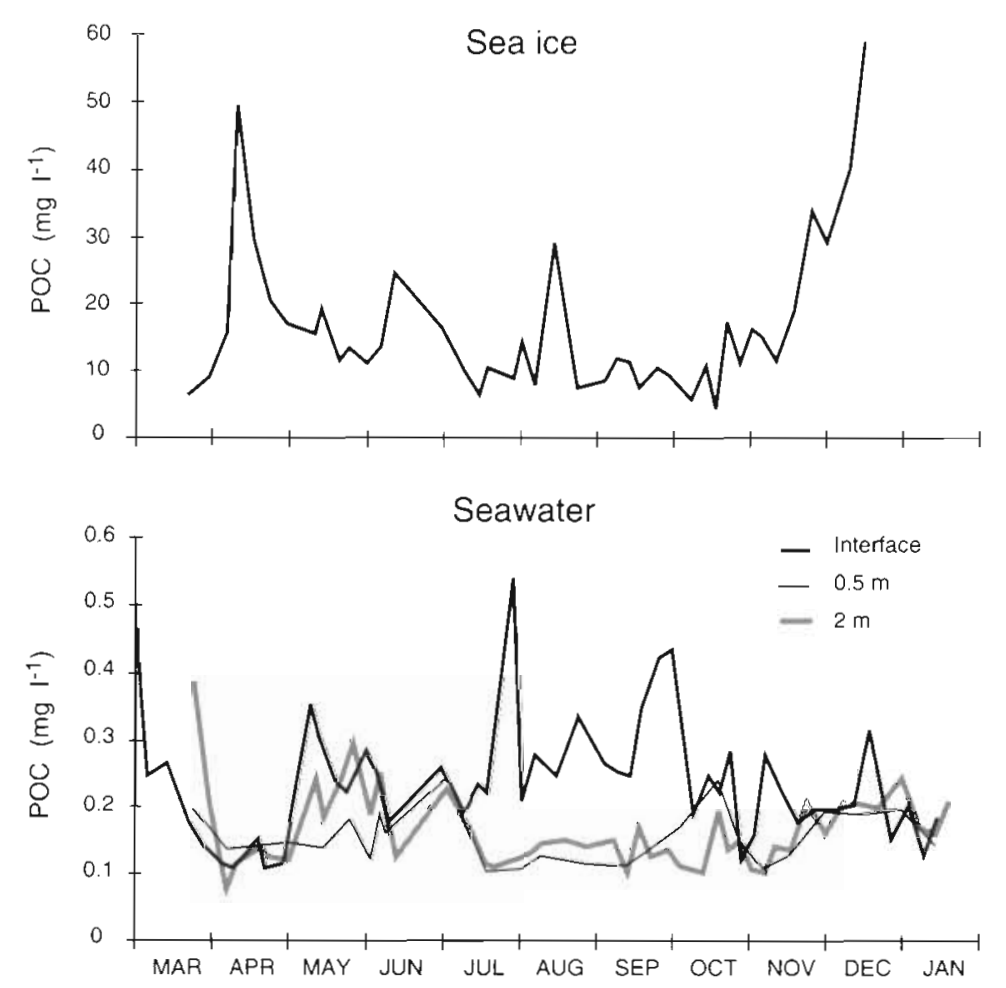

Fig. 3. Comparison of seasonal changes in POC concentrations at the ice bottom and the 3 depths of underlying seawater at Stn B regularly from a few millimeters in early March to more than $1 \mathrm{~m}$ in December (Fig. 2). Water temperature was consistently low, ranging from $0.5^{\circ} \mathrm{C}$ in summer to $-1.7^{\circ} \mathrm{C}$ in winter (data not shown). Solar irradiation ranged from $6 \mathrm{~J} \mathrm{~cm}^{-2} \mathrm{~d}^{-1}$ in June-July to more than $2500 \mathrm{~J} \mathrm{~cm}^{-2} \mathrm{~d}^{-1}$ in December-January.

POC concentrations (Fig. 3) were a hundred times greater in sea ice than in the underlying seawater. Values ranged from about $10 \mathrm{mg} \mathrm{C}^{-1}$ (winter) to more than $50 \mathrm{mg} \mathrm{C} \mathrm{l}^{-1}$ in sea ice, and from 0.1 to $0.5 \mathrm{mg} \mathrm{Cl}^{-1}$ in seawater. Four major distinct peaks (April, June, August and December) were observed in the sea ice. In seawater some differences could be observed among the 3 depths. The winter ice-water interface values were 2 to 5 times larger than those observed in subsurface.

POC/PON ratios (Fig. 4) were much less variable in seawater than in sea ice. There were only very small seasonal changes in seawater and the values recorded at the 3 levels generally were relatively similar. In contrast, after 2 months (April-May), corresponding to the ice-formation period during
Particulate organic matter. Seawater samples were filtered directly upon collection using pre-combusted Whatman GF/F filters. Filters were dried in a vacuum desiccator and then stored frozen. Before measurement they were decalcified by treatment with $1 \mathrm{M} \mathrm{H}_{3} \mathrm{PO}_{4}$ at $60^{\circ} \mathrm{C}$ for $48 \mathrm{~h}$. Particulate organic carbon (POC) and particulate organic nitrogen (PON) were oxidized in a CHN analyser (Perkin Elmer 2400).

Bacterioplankton biomass. Bacterioplankton abundances were determined through epifluorescence after acridine orange staining (Hobbie et al. 1977; Olympus BHA microscope). Cell volumes were estimated using an ocular micrometer. Bacterial biomass was estimated using a conversion factor of $0.4 \mathrm{pg} \mathrm{C} \mathrm{mm}^{-3}$ (Bjørnsen \& Kuparinen 1991).

\section{RESULTS}

\section{Physicochemical data}

The study area was free of ice from January to February. The ice thickness increased
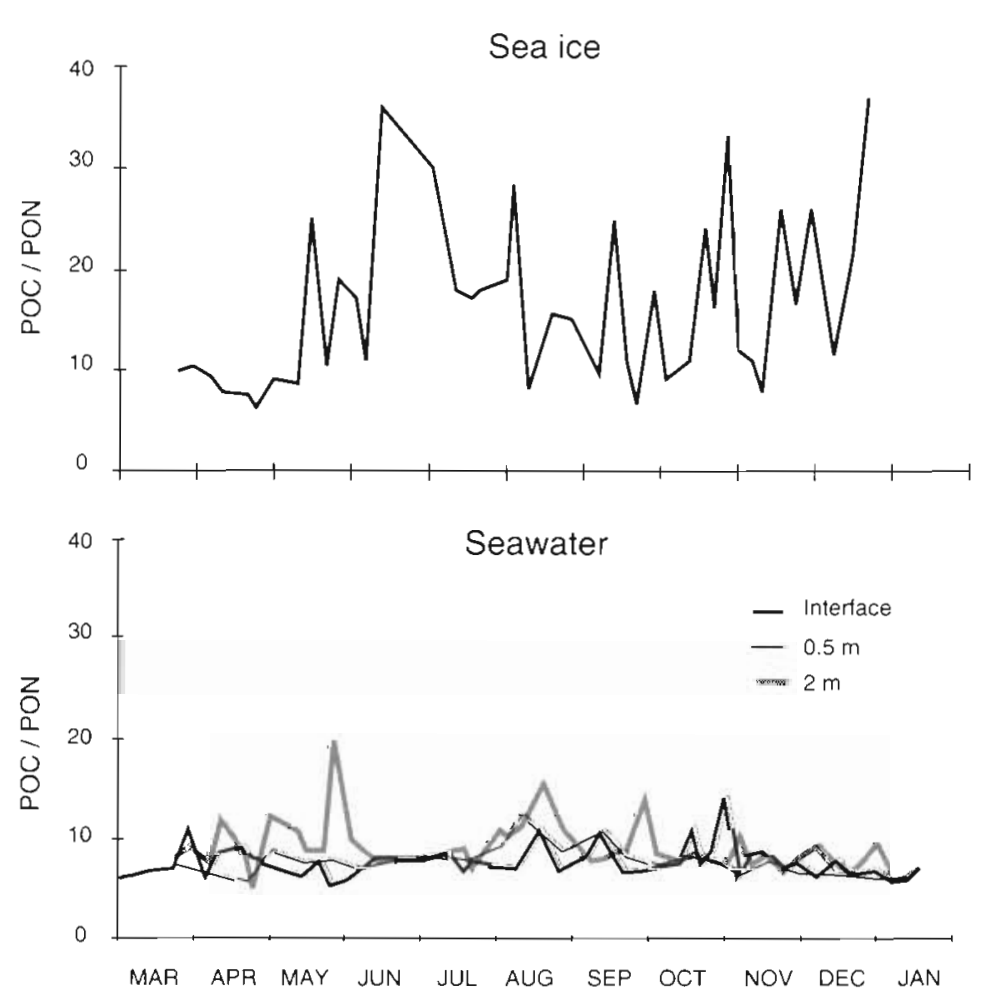

Fig. 4. Comparison of seasonal changes in $\mathrm{C} / \mathrm{N}$ ratio at the ice bottom and the 3 depths of underlying seawater at $\operatorname{Stn} B$ 

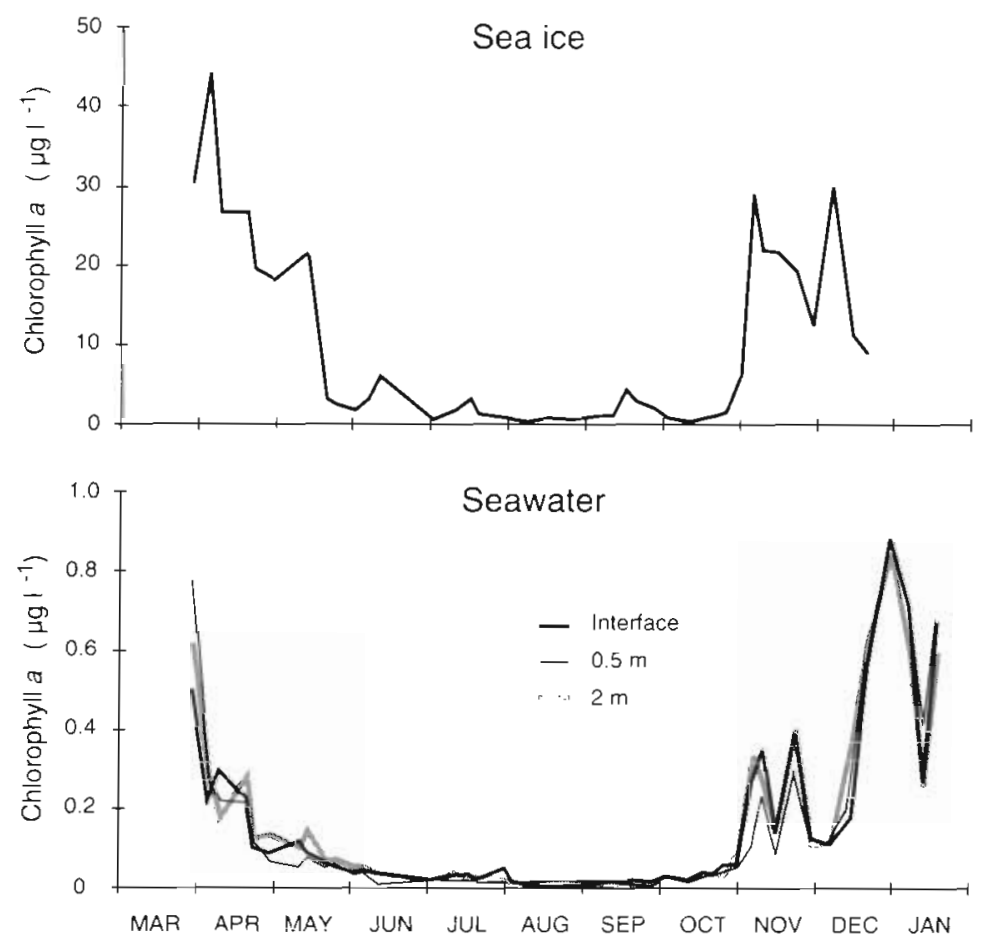

Fig. 5. Comparison of seasonal changes in chl a concentrations at the ice bottom and the 3 depths of underlying seawater at $\operatorname{Stn} B$ present in larger amounts, and the mean chl $c$ / chl a ratio ranged between 0.3 in seawater and 0.48 in sea ice. Diatoms appeared to be dominant, as has been reported in previous work conducted in summer (Fiala \& Delille 1992).

The evolution of phaeopigments was inverse to that of chl a. During winter the mean ratio of phaeopigments to chl a [phaeo a/(chl a + phaeo a)] ranged from 0.3 to 0.5 in sea ice while it was consistently greater than 0.6 in the underlying seawater (Fig. 6). During the summer phytoplankton bloom this ratio was lower and averaged 0.3 in both sea ice and seawater.

\section{Abundance of bacteria}

At the beginning of sea-ice formation a large increase in bacterial abundance occurred in ice-bottom-layer assemblages (Fig. 7). The maximal value of $2.5 \times 10^{6}$ cells $\mathrm{ml}^{-1}$ was reached in April. A steady decrease in cell number then occurred until September. After the winter minima, a small which POC/PON ratios in sea ice were very close to values observed in seawater (ca 10), several very sharp increases, with values greater than 30 (July, October, December), occurred in the sea ice.

\section{Phytoplankton}

During winter, seawater chl a was very low, ranging between 0.01 and $0.05 \mu \mathrm{g}^{-1}$. Concentrations increased dramatically during austral summer to a maximum value of $0.9 \mu \mathrm{g} \mathrm{l}^{-1}$. The observed increase began in November and was made up of a succession of short pulses of limited duration (Fig. 5). Chl a changes recorded in sea ice paralleled those observed in the corresponding seawater samples but were 2 orders of magnitude larger. In winter bottom ice samples, the phytoplankton biomass was always greater than $0.5 \mu \mathrm{g}$ chl a $\mathrm{l}^{-1}$. The maximal values occurred in April during early ice formation (44 $\mu \mathrm{g} \mathrm{chl} \mathrm{a} \mathrm{l}^{-1}$ ) and in November-December just before ice melting (Fj.g. 5).

In both seawater and sea ice the chl $b$ concentration. was negligible. Chl $c$ was
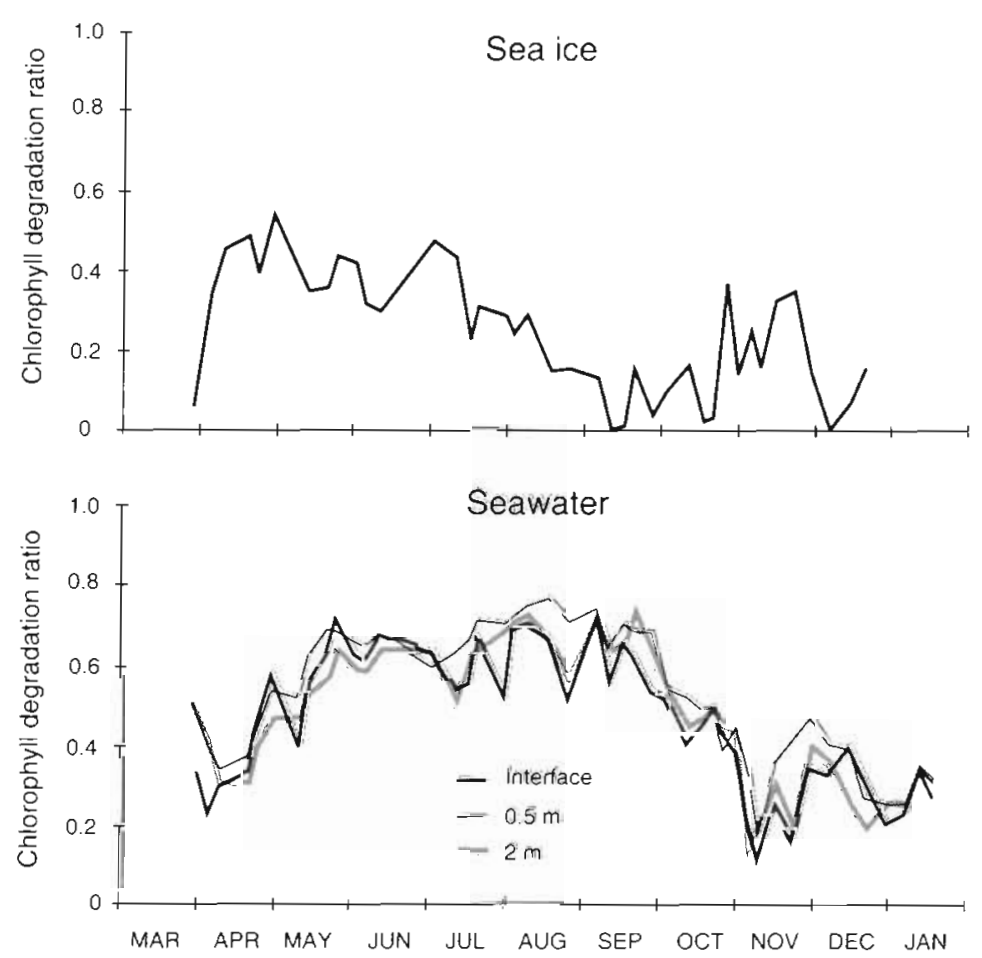

Fig. 6. Comparison of seasonal changes in the degradation ratio [phaeo a/(chl $a+$ phaeo a)] at the ice bottom and the 3 depths of underlying seawater at Stn B 

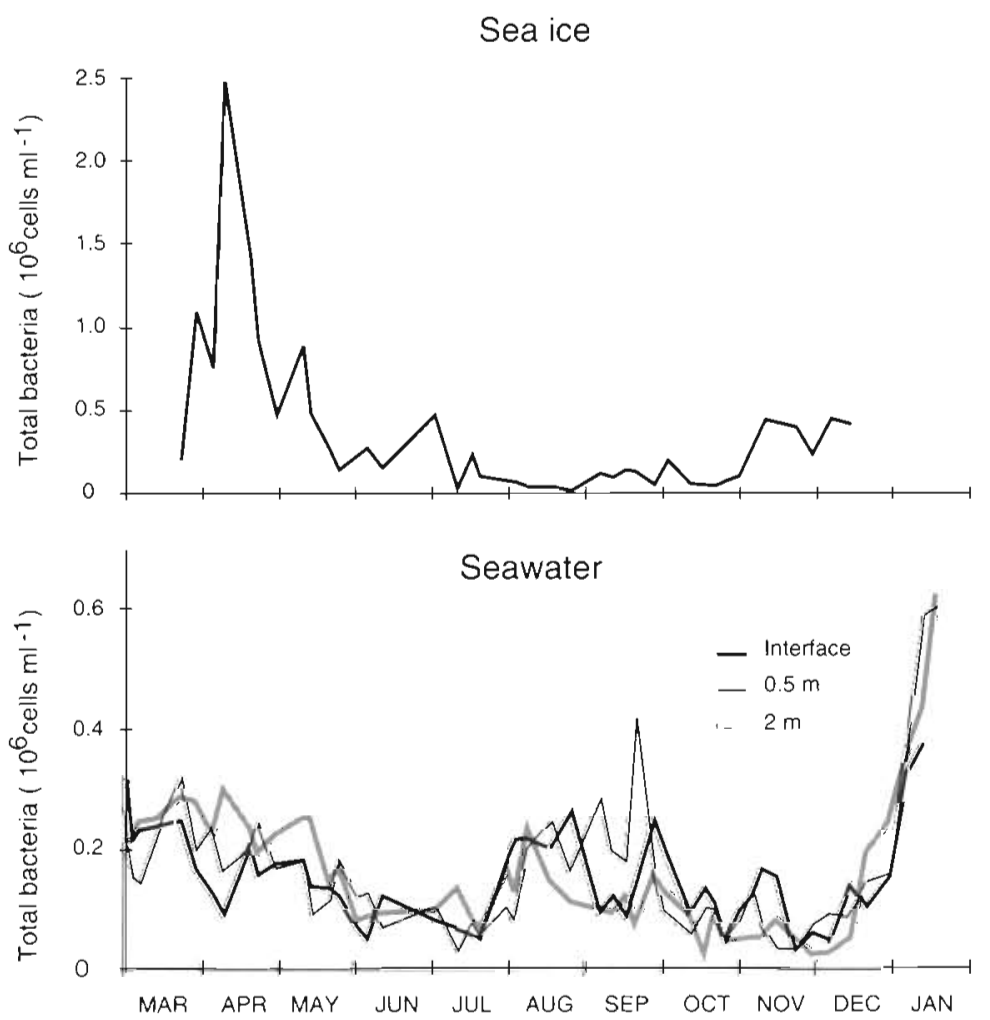

Fig. 7. Comparison of seasonal changes in total bacterial abundance at the ice bottom and the 3 depths of underlying seawater at Stn B plankton decreased in winter: 3 sharp increases in the $\mathrm{POC}$ /phytoplankton $\mathrm{C}$ ratio were found in sea ice (in July, August and October), and a steady increase in these ratios was found in seawater (from April to October).

Comparison between bacterial biomass and chl a concentrations reveals significant correlations in both sea ice and underlying seawater $\left(r^{2}=0.60, p<0.001\right.$, and $r^{2}=0.49$, $\mathrm{p}<0.001$, respectively). Although the mean cell volume of bacteria $\left(0.12 \mu \mathrm{m}^{3}\right)$ was small relative to that of phytoplankton, the estimated bacterial biomass constituted a significant fraction of the total biomass. In sea ice, bacterial carbon accounted for $1 \%$ of total biomass in autumn and spring and for $10 \%$ in winter (i.e phytoplanktonic C/bacterial $\mathrm{C}$ close to 100 and 10 , respectively; Fig. 10). In the underlying seawater, phytoplanktonic and bacterial biomass were of the same order of magnitude from April to July. The bacterial communities predominated from August to October while the algae were dominant in summer (November to early January). increase was recorded in spring and early summer. In seawater, the data collected for the 3 levels were very similar. A small period of increasing abundance was discernible in winter (August-September), although the most striking feature is the strong increase observed just after ice melting (January). Total bacteria ranged from less than $10^{5}$ cells $\mathrm{ml}^{-1}$ in some December samples to more than $0.6 \times 10^{6}$ cells $\mathrm{ml}^{-1}$ in post-melt samples.

The mean bacterial cell volume (Fig. 8) showed the same trend in seasonal variations in both sea ice and underlying seawater. Values ranged from about $0.05 \mu^{3}$

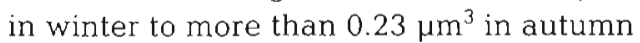
and summer in both sea ice and underlying seawater.

\section{Relationship between bacteria and phytoplankton biomasses}

Phytoplanktonic carbon represented only a relatively small fraction of total POC (Fig. 9). The relative importance of phyto-
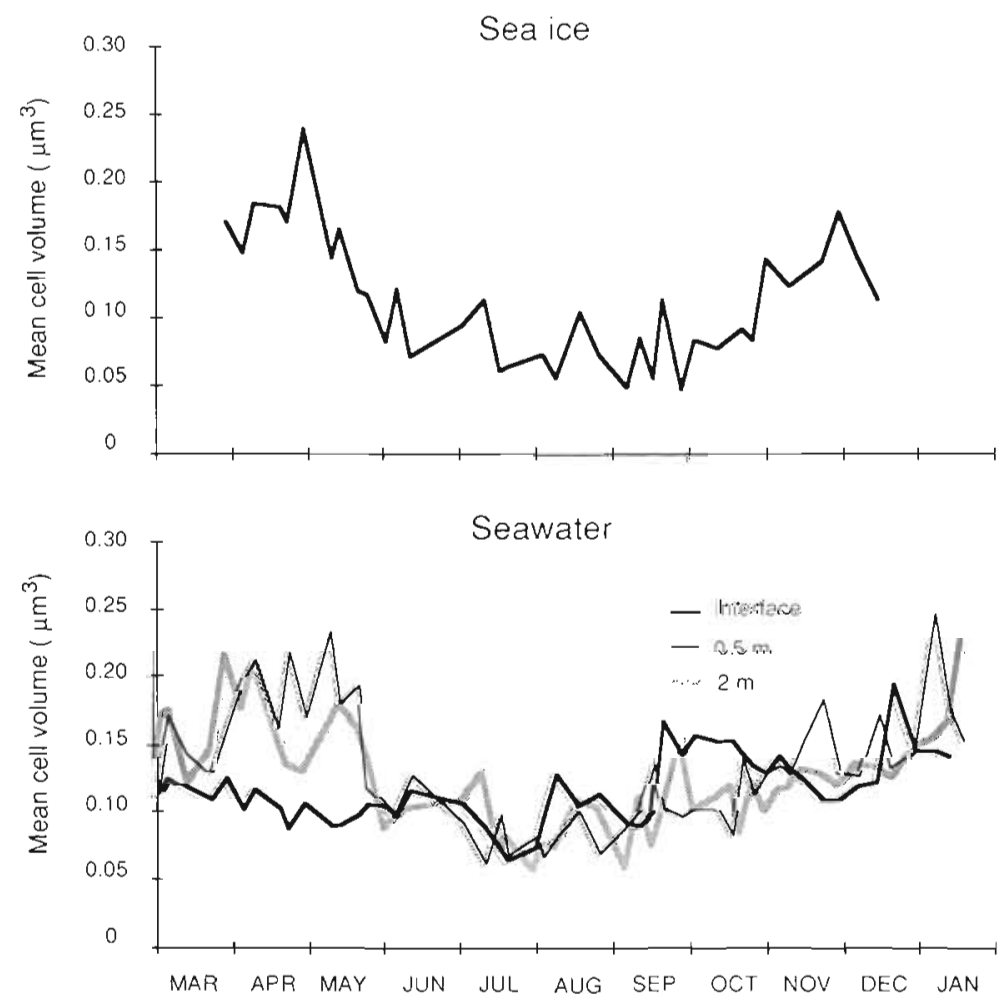

Fig. 8. Comparison of seasonal changes in mean bacterial cell volume at the ice bottom and the 3 depths of underlying seawater at Stn B 

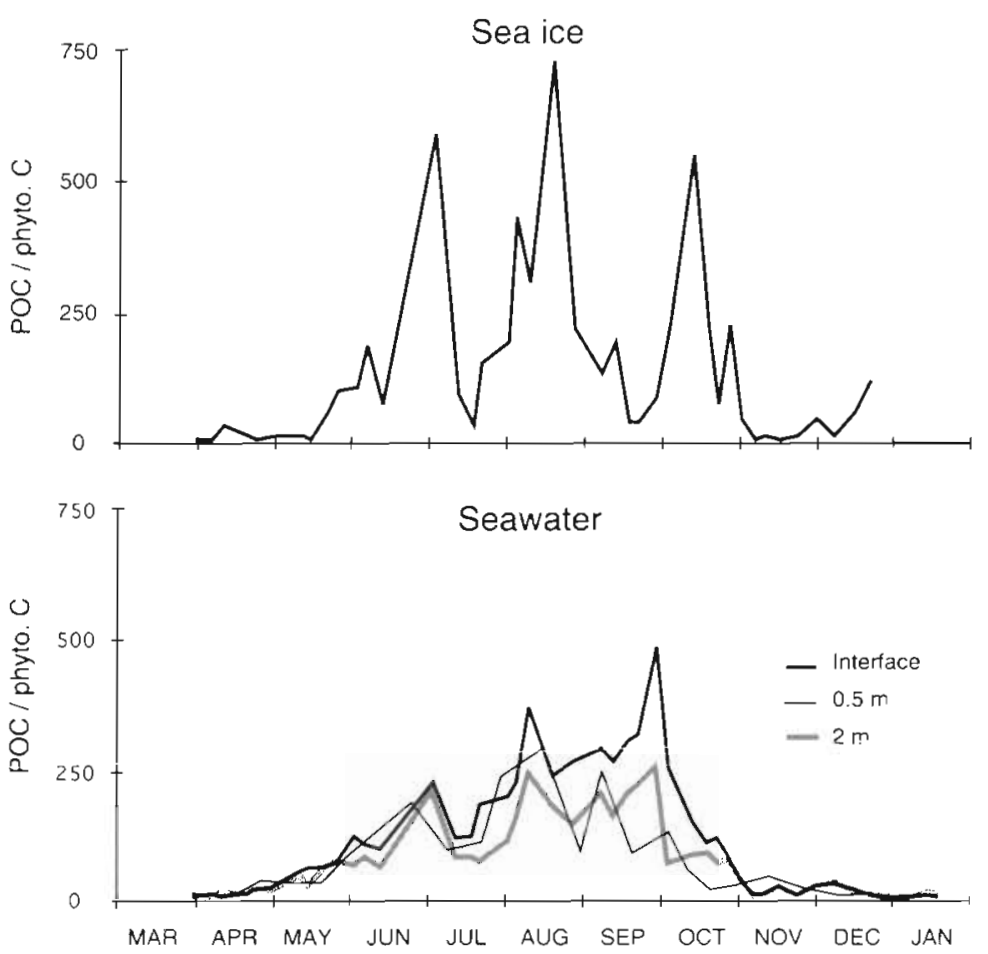

Fig. 9. Comparison of seasonal changes in the POC/phytoplanktonic C ratio recorded at the ice bottom and the 3 depths of underlying seawater at $\operatorname{Stn} B$

\section{DISCUSSION}

POC and PON values observed in seawater were of the same order of magnitude as those reported by other authors in the Ross Sea (Smith \& Nelson 1985, Fabiano et al. 1993) and in the Pacific sector of the Southern Ocean (Tanoue 1985). C/N ratios were low and corresponded to values observed in phytoplankton or bacterial cultures. They were similar to those measured in the Antarctic Peninsula region (Bodungen et al. 1986) and in the Weddell and Ross Seas (Nelson et al. 1989). In sea ice $\mathrm{C} / \mathrm{N}$ ratios were markedly higher, indicating a preferential loss of nitrogen during organic matter decomposition processes, as have been previously reported to occur during particle sedimentation (Muller et al. 1986, Fabiano et al. 1993). The POC/phytoplankton C ratios recorded in winter seawater samples were more than 1 order of magnitude higher than the values reported for more offshore Antarctic samples (Bodungen et al. 1986, Nelson et al. 1989, Fabiano et al. 1993). Such high values of this ratio may be expected in environments characterized by nutrient deficiency (Parsons et al. 1977), low temperatures, low light (Smith \& Nelson 1985) or self-shading (Smith \& Sakshaug 1990), or they may be due to a detrital effect (Treguer et al. 1990). Undoubtedly all these factors operate simultaneously, although the detrital effect may be very important in the coastal area studied (Delille 1993).

The bottom-layer assemblages of the landfast ice in the study area were generally autotrophic. Chl a concentrations in ice-bottom assemblages reached levels considerably greater than those found in the underlying seawater. However, seasonal chl a maxima were relatively low when compared to some of the relevant published data. In platelet ice, the maximum chl a concentration is usually less than $200 \mathrm{mg} \mathrm{m}^{-3}$ (Bunt \& Lee 1970, Grossi et al. 1987) but seasonal chl a maxima ranging from 600 to $2900 \mathrm{mg} \mathrm{m}^{-3}$ have been reported in the bottom layer of landfast ice (Palmisano \& Sullivan 1983, Watanabe et al. 1990). In contrast, springtime chl a concentrations at the ice-water interface which were 1 order of magnitude higher than in bottom ice have been reported in the Arctic (Michel et al. 1993).

Bacterioplankton never constitute a major fraction of the sea ice microbial assemblage. As previously reported (Horner 1985, Grossi et al. 1987, Kottmeier et al. 1987, Garrison \& Close 1993), algae appear to dominate the living biomass, suggesting that losses to consumers are low. However, drastic seasonal changes have been found to occur. Microalgae may be physically enriched within newly forming sea ice by the 'scavenging' effects

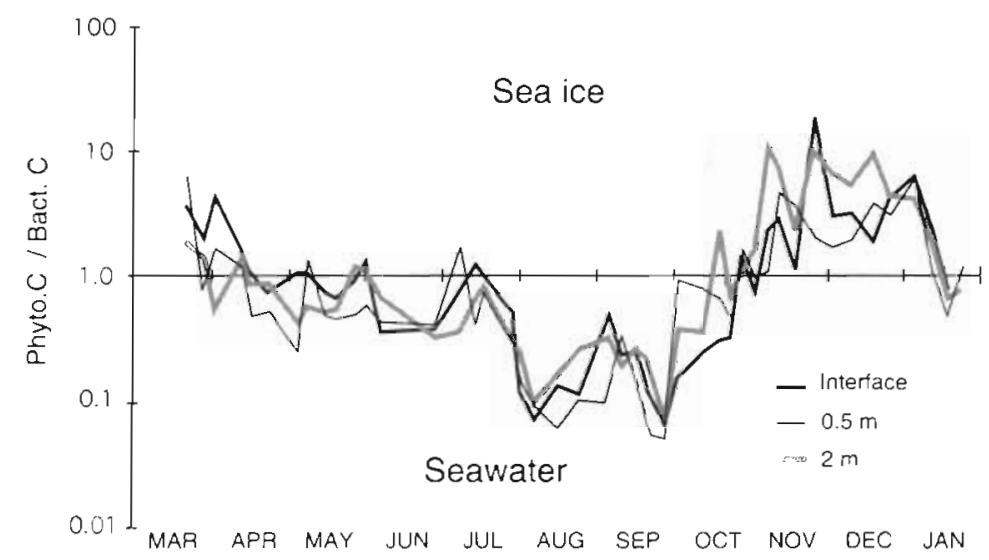

Fig. 10. Comparison of seasonal changes in the phytoplanktonic C/bacterial $C$ ratio recorded at the ice bottom and the 3 depths of underlying seawater at Stn $B$ 
of frazil ice crystals (Garrison et al. 1983, 1989); additionally, enrichment of bacterial cells in new ice in conjunction with phytoplanktonic cells has been observed (Grossmann 1994, Grossmann \& Dieckmann 1994). Such phenomena could explain the bacterial peak observed in the fall. The proportion of bacterial carbon in the total biomass increased from less than $1 \%$ in fall and summer to more than $10 \%$ in winter.

Bacterial cells in sea ice have been reported to be generally larger than those found in the underlying seawater (Delille 1992, Palmisano \& Garrison 1993), which may be a reflection of generally higher organic nutrient concentrations in the ice environment (Marra et al. 1982, Sullivan 1985). This was not confirmed for the bottomlayer assemblages in landfast ice that we studied.

More striking features occurred in the underlying seawater. In winter, calculated ratios of bacterial to algal biomass suggested that bacteria constitute the majority of the microbial assemblage present beneath the ice cover. This observation is consistent with data obtained beneath the Ross Ice Shelf (Karl 1993). However, bacterial abundances observed in the seasonally ice-covered station we studied were more than 1 order of magnitude higher than those reported for the seawater located beneath the Ross Ice Shelf, a permanent floating shelf of glacial ice more than $400 \mathrm{~m}$ thick which completely prevents photosynthesis all year round (Holm-Hansen et al. 1978, Azam et al. 1979). In the summer situation, despite conditions such as reduced wind disturbance, high solar irradiance and high nutrient levels which could potentially support high phytoplankton growth, the studied coastal waters support relatively low levels of algal biomass. However, chl a values were similar to those reported for Antarctic oceanic waters, which typically fall in the range of 0.1 to $1.0 \mathrm{mg} \mathrm{m}^{-3}$ (Weber \& El-Sayed 1987 , Nelson et al. 1989). If the estimated levels of bacterial abundance and biomass are compared to the relevant published data (Hanson et al. 1983, Painting et al. 1985, Delille 1987, 1993, Kottmeier et al. 1987, Rivkin et al. 1989, Karl et al. 1991), it can be seen that these values were fairly low but similar to those in other parts of the Antarctic. The ratios between bacterial and algal biomass are consistent with some of the few field data that are available (Mullins \& Priddle 1987, Fiala \& Delille 1992) and are in agreement with the general assumption that bacterial microflora constitutes on average about $20 \%$ of the total microbial population (Cole et al. 1988). There were no obvious deficits in bacterial cell numbers comparable to those observed in several eutrophic regions of the southern oceans during phytoplanktonic bloom events (Prydz Bay, Lancelot et al. 1989; Weddell-Scotia Sea marginal ice zone, Cota et al. 1990; Southern Bransfield Strait, Karl et al. 1991). However, chl a values never reached con- centrations of $2.5 \mathrm{\mu g} \mathrm{l}^{-1}$ or greater, as reported during these bloom events.

There is strong evidence for algal-bacterial coupling in sea-ice microbial communities. Grossi et al. (1984) found that numbers of bacteria increased with increasing abundance of algae during a spring bloom in McMurdo Sound, Kottmeier et al. (1987) found that bacterial production paralleled the rate of primary production and Priscu et al. (1990) found a significant correlation between dark $\mathrm{CO}_{2}$ fixation and chl $a$. Thus, the positive correlation between algal and bacterial biomass observed in sea ice in this study is not surprising and confirms these previous observations. In contrast, the same correlation observed in seawater is more controversial. Although several examples of correlations between bacteria and phytoplankton have been reported (Fuhrman et al. 1980, Bird \& Kalff 1984, Cole et al. 1988, Tobiesen 1991), such correlations may depend on the scale of the observations (McManus \& Peterson 1988).

In summer, when light is available, the trophic system is classically autotrophic. The parallel increases observed for both bacterial and phytoplankton biomasses in sea ice during fall can be attributed to the harvesting mechanism associated with frazil ice formation (Garrison et al. 1983, 1989, Garrison \& Close 1993). As light intensity decreases, the relative importance of bacterial communities increases. Heterotrophic organisms become dominant in winter when solar irradiation is no longer available. Simon et al. (1992) have shown that the ratio of bacterial carbon biomass to phytoplankton carbon biomass dramatically increases with decreasing phytoplankton abundance. As reported in some oligotrophic oceans (Fuhrman et al. 1989, Cho \& Azam 1990), bacterial biomass in seawater exceeds that of phytoplankton during the polar night. Assuming that aquatic bacteria have a $50 \%$ carbon-based growth efficiency (Suttle et al. 1991), the Antarctic coastal heterotrophic microflora, which exhibit relatively short generation times (Delille et al. 1988, Rivkin et al. 1989), may require a large flux of organic matter. In summer this flux can originate from the primary producers, either directly via phytoplankton exudates or, more likely, indirectly through the action of zooplankton grazing. In winter the accumulated POC, especially in sea ice, will be sufficient to fuel the heterotrophic communities.

Acknowledgements. This research was supported by the 'Institut Français pour la Recherche et la Technologie Polaires' and by 'Expeditions Polaires Françaises' The authors are greatly indebted to G. Marty for the POC and PON analysis and to P. Newton for help in improving the English. We also thank $C$. Lancelot for her careful reading of the manuscript and helpful comments. 


\section{LITERATURE CITED}

Azam F, Beers RJ, Campbell L, Carlucci AF, Holm-Hansen O, Reid $M H$, Karl DM (1979) Occurrence and metabolic activity of organisms under the Ross Ice Shelf, Antarctica, at Station J9. Science 203:451-453

Azam F, Fenchel T, Field JG, Gray JS, Meyer-Reil LA, Thingstad $F$ (1983) The ecological role of water-column microbes in the sea. Mar Ecol Prog Ser 10:257-263

Berman T, Nawrocki M, Taylor GT, Karl DM (1987) Nutrient flux between bacteria, bacterivorous nanoplanktonic protists and algae. Mar microb Food Webs 2:69-82

Bird DF, Kalff J (1984) Empirical relationships between bacterial abundance and chlorophyll concentration in fresh and marine waters. Can J Fish Aquat Sci 41:1015-1023

Bjørnsen PK, Kuparinen J (1991) Determination of bacterioplankton biomass, net production and growth efficiency in the Southern Ocean. Mar Ecol Prog Ser 71:185-194

Bodungen B, Smetacek V, Tilzer MM, Zeitzschel B (1986) Primary production and sedimentation during spring in the Antarctic Peninsula region. Deep Sea Res 33:177-194

Bunt JS, Lee CC (1970) Seasonal. primary production in Antarctic sea ice at McMurdo Sound in 1967 . J mar Res 28: $304-320$

Cho BC, Azam F (1990) Biogeochemical significance of bacterial biomass in the ocean's euphotic zone. Mar Ecol Prog Ser 63:253-259

Cole JJ. Findlay S, Pace ML (1988) Bacterial production in fresh and saltwater ecosystems: a cross-system overview. Mar Ecol Prog Ser 43:1-10

Cota GF, Kottmeier ST, Robinson DH, Smith WO Jr, Sullivan CW (1990) Bacterioplankton in the marginal ice zone of the Weddel: Sea: biomass, production and metabolic activities during austral autumn. Deep Sea Res 37: $1145-1167$

Delille D (1987) Spatial distribution of coastal Antarctic seawater bacteria: relationship with avifauna. Polar Biol 8: $55-60$

Delille D (1990) Seasonal changes of subantarctic heterotrophic bacterioplankton. Arch Hydrobiol 1.19:267-277

Delille D (1992) Manne bacterioplankton at the Weddell Sea ice edge, distribution of psychrophilic and psychrotrophic populations. Polar Biol 12:205-210

Delille D (1993) Seasonal changes in the abundance and composition of marine heterotrophic bacterial communities in an Antarctic coastal area. Polar Biol 13:463-470

Delille D, Bouvy M, Cahet G (1988) Short term variations of bacterioplankton in Antarctic zone: Terre Adélie area. Microb Ecol 15:293-309

Ducklow HW, Kirchman DL, Quinby HL, Carlson CA, Dam HG (1993) Bacterioplankton carbon cycling during the spring bloom in the eastern North Atlantic Ocean. Deep Sea Res II 40:245-263

Ducklow HW, Purdie DA, Williams PJLeB, Davies JM (1986) Bacterioplankton: a sink for carbon. in a coastal marine plankton community. Science 232:865-867

Ducklow HW, Shiah FK (1993) Bacterial production in estuaries. In: Ford TG (ed) Aquatic microbiology: an ecological approach. Blackwell Scientific Publications, Boston, p $261-287$

Fabiano M, Povero P, Danovaro R (1993) Distribution and composition of particulate organuc matter in the Ross Sea (Antarctica). Polar Biol 13:525-533

Fiala M, Delille D (1992) Variabiluty and interactions of phytoplankton and bacterioplankton in the Antarctic neritic area. Mar Ecol Prog Ser 89:135-146

Fuhrman JA, Ammerman JW, Azam F (1980) Bacterioplank- ton in the coastal euphotic zone: distribution, activity and possible relationships with phytoplankton. Mar Biol 60; 201-207

Fuhrman JA, Sleeter TD, Carlson CA, Proctor LM (1989) Dominance of bacterial biomass in the Sargasso Sea and its ecological implications. Mar Ecol Prog Ser 57:207-217

Garrison DL, Ackley SF, Buck KR (1983) A physical mechanism for establishing algal populations in frazil ice. Nature 306:363-365

Garrison DL, Close AR (1993) Winter ecology of the sea ice biota in Weddell Sea pack ice. Mar Ecol Prog Ser 96:17-31

Garrison DL, Close AR, Reimntz E (1989) Algae concentrated by frazil ice: evidence from laboratory and field measurements. Antarct Sci 1:313-316

Griffith PC, Douglas DJ, Wainright SC (1990) Metabolic activity of size-fractionated microbial plankton in estuarine, nearshore, and continental shelf waters of Georgia. Mar Ecol Prog Ser 59:263-270

Grossi SM, Kottmeier ST, Moe RL, Taylor GT, Sullivan CW (1987) Sea ice microbiai communities. VI. Growth and primary productivity in bottom ice under graded snow cover. Mar Ecol Prog Ser 35:153-164

Grossi SM, Kottmeier ST, Sullivan CW (1984) Sea ice microbial communities. III. Seasonal abundance of microalgae and associated bactera. McMurdo Sound, Antarctica. Microb Ecol 10:231-242

Grossmann S (1994) Bacterial activity in sea ice and open water of the Weddell Sea, Antarctica: a microautoradiographic study. Microb Ecol 28:1-18

Grossmann S, Dieckmann GS (1994) Bacterial standing stock, activity, and carbon production during formation and growth of sea ice in the Weddell Sea, Antarctica. Appl environ Microbiol 60:2746-2753

Hanson RB, Schafer D, Ryan T, Pope DH, Lowery HK (1983) Bacterioplankton in antarctic ocean waters during late austral winter: abundances, frequency of dividing cells, and estimates of production. Appl environ Microbiol 45 $1622-1632$

Hobbie JE, Daley RJ, Jasper S (1977) Use of Nuclepore filters for counting bacteria by fluorescence microscopy. Appl environ Microbiol 33:1225-1228

Hoch MP, Kirchman DL (1993) Seasonal and inter-annual variability in bacterial production and biomass in a temperate estuary. Mar Ecol Prog Ser 98:283-295

Holm-Hansen O, Azam F, Campbell L, Carlucci AF, Karl DM (1978) Microbial life beneath the Ross Ice Shelf. Antarct J US $13: 129-130$

Hopkinson CS (1985) Shallow-water benthic and pelagic metabolism: evidence of heterotrophy in the nearshore Georgia Bight. Mar Biol 87:19-32

Hopkinson CS, Sherr BF, Wiebe WJ (1989) Size fractionated metabolism of coastal microbial plankton. Mar Ecol Prog Ser 51:155-166

Horner RA (1985) Ecology of sea ice microalgae. In: Horner RA (ed) Sea ice biota. CRC Press, Boca Raton, p 83-103

Karl DM (1993) Microbial processes in the southern oreans. In: Friedmann El (ed) Antarctic microbiology. Wiley-Liss, New York, p 1-63

Karl DM, Holm-Hansen O, Taylor GT, Tien G, Bird DF (1991) Microbial biomass and productivity in the western Bransfield Strait, Antarctica during the 1986-87 austral summer. Deep Sea Res 89:1029-1055

Kottmeier ST, Grossi SW, Sullivan CW (1987) Sea ice microbial communities. VIII. Bacterial production in annual of McMurdo Sound, Antarctica. Mar Ecol Prog Ser 35: $175-186$

Kuosa H, Kivi K (1989) Bacteria and heterotrophı flagellates 
in the pelagic carbon cycle in the northern Baltic Sea. Mar Ecol Prog Ser 53:93-100

Lancelot C. Billen G (1984) Activity of heterotrophic bacteria and its coupling to primary production during the spring phytoplankton bloom in the southern bight of the North sea. Limnol Oceanogr 29:721-730

Lancelot C, Billen G, Mathot S (1989) Ecophysiology of phytoand bacterioplankton growth in the Southern Ocean. In: Caschetto S (ed) Plankton ecology, Vol 1. Science Policy Office, Brussels, p 1-97

Marra J, Burckle LH, Ducklow HW (1982) Sea ice and water column plankton distributions in the Weddell Sea in late winter. Antarct J US 27:111-112

McManus GB, Peterson WT (1988) Bacterioplankton production in the nearshore zone during upwelling off central Chile. Mar Ecol Prog Ser 43:11-17

Michel C, Legendre L, Therriault JC, Demers S, Vandevelde T (1993) Springtime coupling between ice algal and phytoplankton assemblages in southeastern Hudson Bay, Canadian Arctic. Polar Biol 13:441-449

Muller PJ, Suess E, Ungerer A (1986) Amino acids and amino sugars of surface particulate and sediment trap material from waters of the Scotia Sea. Deep Sea Res 33:819-838

Mullins BW, Priddle J (1987) Relationships between bacteria and phytoplankton in the Bransfield Strait and southern Drake passage. Br Antarct Surv Bull 76:51-64

Nelson DM, Smith WO Jr, Muench RD, Gordon LI, Sullivan CW, Husby DM (1989) Particulate matter and nutrient distributions in the jce-edge zone of the Weddell sea: relationship to hydrography during late summer. Deep Sea Res 36:191-209

Neori A, Holm-Hansen O (1982) Effect of temperature on rate of photosynthesis in antarctic phytoplankton. Polar Biol 1. $33-38$

Neveux J, Panouse M (1987) Spectrofluorometric determination of chlorophylls and pheophytins. Arch Hydrobiol 109: $567-561$

Painting SJ, Lucas MI, Stenton Dosey JME (1985) The South african SIBEX I cruise to the Prydz Bay region, 1984: X. Biomass and production of bacterioplankton in Prydz Bay, Antarctica, and phytoplankton, detritus and bacterial relationships. S Afr Tydskr Antarkt Nav 15:42-52

Palmisano AC, Garrison DL (1993) Microorganisms in Antarctic sea ice. In: Friedmann El (ed) Antarctic microbiology. Wiley-Liss, New York, p 167-218

Paimisano AC, Sullivan CW (1983) Sea ice microbial communities (SIMCO) I. Distribution, abundance and primary production of ice microalgae in McMurdo Sound, Antarctica in 1980. Polar Biol 2:171-177

Parsons TR, Takahashi M. Hargrave B (1977) Biological oceanographic processes. Pergamon Press, New York

Platt T, Sathendranath S, Ulloa O, Harrison WG, Hoepffner N, Goes J (1992) Nutrient control of phytoplankton photosynthesis in the western North Atlantic. Nature 356:229-231

Pomeroy LR, Deibel D (1986) Temperature regulation of bacterial activity during the spring bloom in Newfoundland coastal waters. Science 233:359-361

Priscu JC, Downes MT, Priscu LR, Palmisano AC, Sullivan CW (1990) Dynamics of ammonium oxidizer activity and nitrous oxide $\left(\mathrm{N}_{2} \mathrm{O}\right)$ within and beneath Antarctic sea ice. Mar Ecol Prog Ser 66:37-46

This article was presented by $O$. Holm-Hansen (Senior Editorial Advisor), La Jolla, California, USA
Riemann B, Sondergaard GA (1986) Regulation of bacterial secondary production in two eutrophic lakes and in experimental enclosures. J Plankton Res 8:519-536

Rivkin RB, Putt M, Alexander SP, Meritt D, Gaudet L (1989) Biomass and production in polar planktonic and sea ice microbial communities: a comparative study. Mar Biol 101 273-283

Simon M. Cho BC, Azam F (1992) Significance of bacterial biomass in lakes and the ocean: comparison to phytoplankton biomass and biogeochemical implications. Mar Ecol Prog Ser 86:103-110

Smith SV, Mackenzie FT (1987) The ocean as a net heterotrophic system: implication from the carbon biogeochemical cycle. Global biogeochem Cycles 1:187-198

Smith WO, Nelson DM (1985) Phytoplankton bloom produced by a receding ice-edge in the Ross Sea: spatial coherence with the density field. Science 227:163-166

Smith WO, Sakshaug E (1990) Polar phytoplankton. In: Smith WO (ed) Polar oceanography, Part B. Academic Press, San Diego, p $477-525$

Suttle CA, Chan AM, Fuhrman JA (1991) Dissolved free amino acids in the Sargasso Sea: uptake and respiration rates, turnover times, and concentrations. Mar Ecol Prog Ser 70:189-199

Sullivan CW (1985) Sea ice bacteria: reciprocal interactions of the organisms and their environment. In: Horner RA (ed) Sea ice biota. CRC Press, Boca Raton, p159-171

Tanoue E (1985) Distribution and chemical composition of particulate organic matter in the Pacific sector of the Antarctic Ocean. Trans Tokyo Univ Fish 6:43-57

Tobiesen A (1991) The succession of microheterotrophs and phytoplankton within the microbial loop in Oslofjorden May-October 1984. J Plankton Res 13:197-216

Treguer P, Nelson DM, Gueneley S, Zeyons C, Morvan J Buma $A(1990)$ The distribution of biogenic and lithogenic silica and the composition of particulate organic matter in the Scotia Sea and the Drake Passage during autumn 1987. Deep Sea Res 37:833-851

Vaqué D, Pace ML, Findlay S, Lints D (1992) Fate of bacterial production in a heterotrophic ecosystem: grazing by protists and metazoans in the Hudson Estuary. Mar Ecol Prog Ser 89:155-163

Velimirov B, Walenta-Simon M (1992) Seasonal changes in specific growth rate, production, and biomass of bacterial community in the water column above a Mediterranean seagrass system. Mar Ecol Prog Ser 80:237-248

Watanabe K, Satoh H, Hoshiai T (1990) Seasonal variation in ice algal assemblages in the fast ice near Syowa Station in 1983/84. In: Kerry KR, Hempel G (eds) Antarctic ecosystems, ecological change and conservation. SpringerVerlag, Berlin, p 136-142

Weber LH, E]-Sayed SZ (1987) Contribution of the net, nanoand picoplankton standing crop and primary productivity in the Southern Ocean. J Plankton Res 9:973-994

Wiebe WJ, Sheldon WM, Pomeroy LR (1993) Evidence for an enhanced substrate requirement by marine mesophilic bacterial isolates at minimal growth temperatures. Microb Ecol 25:151-159

Wylie JL, Currie DJ (1991) The relative importance of bacteria and algae as food sources for crustacean zooplankton. Limnol Oceanogr 36:708-729

Manuscript first received: April 15, 1994

Revised version accepted: February 7, 1995 